\title{
CHEMICAL AND RHEOLOGICAL STUDIES ON TALBEENA AS A TRADITIONAL HEALTHY BEVERAGE Elzayet, Fatma M. ${ }^{1}$; H.A. Shehata ${ }^{1}$ Mofeda T. Attia ${ }^{1}$ and Al-Zahraa, M. Motawei. ${ }^{2}$ ${ }^{1}$ Food Technology Dept. -Faculty of Agriculture- Suez Canal University ${ }^{2}$ Food Industries Dept. -Faculty of Agriculture- Mansoura University
}

\begin{abstract}
This study aims to examine the possibility of producing Talbeena, using whole barley and malt flours with skimmed milk or full-cream milk compared with a reference control treatment (with water only). Chemical investigation included $\beta$ glucan determination, minerals content $(\mathrm{Na}, \mathrm{K}, \mathrm{Ca}, \mathrm{P}, \mathrm{Fe}$, and $\mathrm{Zn})$, beside the other basic nutritional components in both raw materials and corresponding products was done. Viscosity was measured as an important rheological property and a strong indicator on $\beta$-glucan functionality. All treatments were examined organolyptically. Obtained results showed that barley flour gave the highest content of ash, crude fiber and fat compared to malt flour. Moreover, barley flour Talbeena gave the highest content of the minerals ( $\mathrm{Na}, \mathrm{K}, \mathrm{Ca}, \mathrm{P}, \mathrm{Fe}$, and $\mathrm{Zn}$ ) compared with malt flour talbeena. $\beta$-glucan results showed that malt flour treatments scored the lowest content while, $\beta$ glucan solubility increased by malting. Skimmed milk treatments registered the highest content of carbohydrates, protein and ash as well as minerals $(\mathrm{Na}, \mathrm{K}, \mathrm{Ca}, \mathrm{P}$, and $\mathrm{Zn}$ ) compared with full-cream milk, which was higher in iron content. Viscosity was higher in control and skimmed milk barley flour Talbeenas compared with others. Sensory evaluation of samples showed superiority of malt with full cream milk talbeena than other treatments. . Presented Content of $\beta$-Glucan in barley flour talbeena, meet the recommended daily needs to achieve the health benefits attributed to barley $\beta$-gucan.
\end{abstract}

\section{INTRODUCTION}

The increasing prevalence of public health problems related to a sedentary life style has been widely discussed (WHO, 2003). The challenge for consumers is to gather a diet from the individual products available on the market, although the nutritional goals are satisfied overall diet. The noticeable development of health promoting diet called Functional Foods has been on the focus. A key perspective to understand the role of functional foods is to emphasis the role of functional foods as a socially and culturally shaped phenomenon instead of mere products to be accepted or rejected (Niva, 2007). That why we should search in our heritage and local environment for more healthy substitutes.

As a healthy food, there has been a growing research interest for the utilization of barley in a wide range of food applications (Erkan et al., 2006). Apart from having a nutritive value, barley is unique among cereals for its healthy effects. Barley is the main cereal grain for the development of functional foods, as it contains high concentrations of many components of strong healthy interest. Consuming barley lowers the levels of blood cholesterol and attenuates postprandial glucose response (Cavallero et al., 2002 and lyly, 2006). Consumption of barley-containing foods and the 
associated soluble fiber significantly improved several cardiovascular disease risk factors. The mixed linkage (1-3)(1-4)-b-D-glucans (b-glucan) from the endosperm of barley grains are valuable industrial hydrocolloids and have been shown to be important, physiologically active dietary fibre components. Cereals especially oat and barley are rich in b-glucan. (Wood et al., 2000).The highest B-glucan intake resulted in the greatest reduction in total and LDL-cholesterol concentrations and total HDL cholesterol, especially in postmenopausal women and men as reported by (Behall, 2004). The Food and Drug Administration had allowed foods containing barley to claim that they reduce the risk of coronary heart disease. provide at least 0.75 grams of soluble fiber per serving (FDA, 2006) which may have a positive impact on the consumption of this grain, that consumption level may start rising in the near future. Talbeena-like beverage in the Tibet is called tsangpa it is roasted hulless barley grain flour. It can be added to tea, skim milk, or even cold water and consumed as a beverage. Many people mix it with sugar and eat it directly (Nyima, 2005). It is important to refer to that Prophet Muhammad $(\mathrm{PBUH}))$ recommended barley and used it in various forms such as barley bread and Talbeena as mentioned by Ibn Al Qayyim Al Jawziyyah (1957).

So, the present study was designed to investigate the possibility of producing healthy, high quality traditional Talbeena using hulless barley flour $(87.2 \%)$ and malt flour and how these healthy foods are influenced chemically and organolyptically by the addition of milk (skimmed or full cream). Also, to investigate how modifications affect the perceived rheological, and nutritional quality as well as health functional properties. On the way to produce a feasible strategy for involving such a healthy food in our traditional staple foods.

\section{MATERIALS AND METHODS}

\section{Materials: \\ Raw materials:}

Barley grains, the six rowed naked barley cultivar (Hordeum vulgare vulgare L.) Giza 130 grains were obtained from Barley Research Department, Crop Research Institute, Agriculture Research Center, Giza, Egypt. Dry Skimmed and full cream milk were purchased from local markets. Methods:

Milling process: Hull-less barley was milled into flour using Brabender pilot automatic mill (mill senior Brabender, Mod. No.8802, Germany), with a milling yield of $63.7 \%$. The fine bran was re-mixed with the flour again, and then sieved through $0.5 \mathrm{~mm}$ sieve to produce flour $87.2 \%$.

Malting: Malt was produced from barley grains as described by (Aly, 1997).

Talbeena: Popular Traditional beverage "Talbeena" was prepared according to (Ibn Al Qayyim Al Jawziyyah, 1957 ) using some modifications to improve sensory and nutritional quality as follows: $100 \mathrm{ml}$ water, $4 \mathrm{gm}$ flour (barley,or malt), $6 \mathrm{gm}$ sugar, with or without $10 \mathrm{gm}$ dried milk (skimmed or full cream "Nido") were mixed vigorously, then stirred for $5 \mathrm{~min}$ over moderate stove. 
After that, still hot samples were subjected to the sensory and rheological analyses.

Chemical Analyses:

Moisture, ash, protein, crude fiber, and fat contents were determined according to the methods described by (A.O.A.C, 2000).

-Determination of minerals content: Sodium, potassium and Calcium were determined using flame photometer according to (Hesse, 1971). Phosphorus compound was determined using the spectrophotometric method (Jackson, 1967). Iron and zinc contents were determined according to (Puspa et al., 1994).

Determination of total $\beta$-glucan: $\beta$-glucan was determined by a non enzymatic method according to (Madacsi et al 1983).

Determination of solubility of $\beta$-glucan samples: The solubility of $\beta$ glucan (unpurified) in the native flour was determined according to the method of GaoSong and Vasanthan (2000).

Viscosity measurement: viscosity of Talbeena samples was measured with Brookfield RVDV-II+ viscometer (Brookfield, United Kingdom) including the temperature of samples at the time of measurement ( 40 degrees Celsius), with angular speed of $10 \mathrm{rpm}$ and spindles between numbers 5 and 7 . Viscosities measured at shear rate $50 \mathrm{~s}^{-1}$. The shear rate was chosen as it has been shown to correlate with sensory sliminess and thickness in mouth feel as stated by (Lyly et al, 2004).

All samples evaluated sensorically by panelists were measured. Two replicate measurements per sample were conducted; and the average value of the apparent viscosity (reported as the mean shear rate of the measurement taken at $50 \mathrm{~s}-1$ ) measurements was used in the statistical analysis.

Sensory evaluation of Talbeena: Samples of Talbeena were committed to the sensory evaluation by 20 panelists from staff members of Food technology Dept., Faculty of Agriculture, Suez Canal University. Talbeena hot samples were evaluated for taste, appearance, mouth feel, and odor. The characteristics were scored on a scale of 1 to 10 as described by Lyly (2006).

\section{RESULTS AND DISCUSSION}

\section{Chemical composition of Talbeena:}

The compared determination of the proximate analysis of Talbeena raw materials shown in table (1), illustrated that, barley flour had higher protein, ash, fat, and crude fiber than malt flour; this is because of the hydrolysis during germination which characterized with high enzymatic activity. In the same table, likewise, skimmed milk had higher ash, protein, and total carbohydrates contents than full cream milk while, the later was superior in its fat content. .Proximate composition of skimmed milk and full cream milk were confirmed by (Eckles et al, 1951). These results were in agreement with (Assem et al, 2002) who found that, chemical composition of whole barley flour showed protein content $12.9 \%$, ash $2.95 \%$, crude fiber $3.9 \%$, lipids $2.43 \%$, and total carbohydrates $76.71 \%$. The increases in 
protein and fat contents may due to that; they used whole $100 \%$ flour, beside genotype and environmental variations. Moreover, (Tamime et al, 1997) reported $2.4 \%$ ash, $12.8 \%$ protein, and $3.5 \%$ fat in barley grains.

Table (1): Chemical composition of Talbeena ingredients (gm $\backslash 100 \mathrm{gm}$ ) on dry weight basis:-

\begin{tabular}{|c|c|c|c|c|c|c|c|c|c|c|}
\hline $\begin{array}{l}\text { Components } \\
\text { Raw materials }\end{array}$ & \multicolumn{2}{|c|}{ Moisture\% } & \multicolumn{2}{|c|}{$\begin{array}{l}\text { Crude } \\
\text { Protein }\end{array}$} & $\begin{array}{l}\text { Crude } \\
\text { Fat }\end{array}$ & Ash & \begin{tabular}{|l} 
Crude \\
fiber
\end{tabular} & \multicolumn{2}{|c|}{$\begin{array}{c}\text { Total } \\
\text { Carbohydrate }\end{array}$} & $\begin{array}{c}\text { Energy } \\
\text { (kcal/ } \\
100 \mathrm{~g}) \\
\end{array}$ \\
\hline Barley flour & $\begin{array}{l}1 \cdot, 70 \\
\pm \cdot, 16\end{array}$ & $a$ & $\begin{array}{l}\cdot, 19 \\
\pm \cdot, 40\end{array}$ & $\mathrm{a}$ & \begin{tabular}{|c|c|}
$1,9 \leq$ & $a$ \\
$\pm \cdot, \cdot 8$ & \\
\end{tabular} & \begin{tabular}{|c|c}
,$r q$ & $a$ \\
$\pm \cdot, \cdot \varepsilon$ &
\end{tabular} & $\left.$\begin{tabular}{|c|c}
2.23 \\
\pm 0.11
\end{tabular}\right|$^{a}$ & $\begin{array}{l}82.55 \\
\pm \cdot, 4\end{array}$ & $a$ & $\begin{array}{c}391.22 \\
\pm 1 r .1\end{array}$ \\
\hline Malt flour & $\begin{array}{l}r, r 1 \\
\pm \cdot, Y T\end{array}$ & b & $\begin{array}{l}11.91 \\
\pm \cdot, 09 \\
\end{array}$ & $\mathrm{a}$ & \begin{tabular}{|c|c|}
1.74 & $a$ \\
$\pm \cdot, r y$ & \\
\end{tabular} & \begin{tabular}{|c|c|}
$r, 0$ & $b$ \\
$\pm \cdot, \cdot r$ & \\
\end{tabular} & \begin{tabular}{c|c}
2.01 & $b$ \\
\pm 0.03 & \\
\end{tabular} & $\begin{array}{l}82.29 \\
\pm 0.72 \\
\end{array}$ & $\mathrm{a}$ & $\begin{array}{c}392.46 \\
\pm r, 12\end{array}$ \\
\hline \begin{tabular}{|l|} 
LSD / Sign (P $\leq$ \\
$0.05)$
\end{tabular} & 0.585 & & $1.103^{N}$ & & $0.589^{\text {N.S }}$ & $0.078^{\star *}$ & $0.016^{\star *}$ & 1.290 & & $3.337^{\text {N.S }}$ \\
\hline Skimmed milk & $\begin{array}{l}\varepsilon, 9 T \\
\pm \cdot, r \varepsilon\end{array}$ & b & $\begin{array}{l}r r, 0 T \\
\pm \cdot, r q\end{array}$ & $\mathrm{a}$ & \begin{tabular}{|c|}
$\cdot, 9 \cdot$ \\
$\pm \cdot, \cdot \wedge$
\end{tabular} & \begin{tabular}{|c|}
$v, 97$ \\
$\pm \cdot, 11$
\end{tabular}${ }^{a}$ & N.D & $\begin{array}{l}\text { ON,OV } \\
\pm \cdot, r 4\end{array}$ & $a$ & $\begin{array}{l}r V r \\
., 71\end{array}$ \\
\hline Full cream milk & $\begin{array}{l}V, \leqslant 0 \\
\pm \cdot, r Y\end{array}$ & $\mathrm{a}$ & $\begin{array}{l}\text { YO, } \varepsilon . \\
\pm \cdot, r\end{array}$ & $\mathrm{~b}$ & \begin{tabular}{|l|l|}
$r \wedge, \leqslant \wedge$ & $a$ \\
$\pm *, \cdot 9$ & \\
\end{tabular} & \begin{tabular}{|c|c|}
$7, r T$ & $b$ \\
$\pm \cdot, \cdot T$ & \\
\end{tabular} & N.D & $\begin{array}{l}39.89 \\
\pm 0.22 \\
\end{array}$ & $\mathrm{~b}$ & $\begin{array}{c}011 \\
\pm \cdot, 72 \\
\end{array}$ \\
\hline \begin{tabular}{|l} 
LSD / Sign (P $\leq$ \\
$0.05)$
\end{tabular} & 0.750 & & $0.717^{\star}$ & & $0.193^{\star \star}$ & $0.208^{\star \star}$ & -- & & & $1.309^{\star \star}$ \\
\hline
\end{tabular}

Values in the same column with different letters (a \& b) are significantly different (P $\leq$ 0.05).

All values are means of three replicates \pm SD on dry weight basis.

Table (2) showed the chemical analysis of Talbeena samples for each $100 \mathrm{ml}$ wet basis. Unsurprisingly, chemical composition of Talbeena samples made with barley flour high significantly differed from that made from malt flour. The crude protein, total carbohydrates and ash contents increased with the addition of skimmed milk than full cream milk, the later increased significantly fat content. Reasonably, differences were due to type of added milk, not to the type of flour. It is worthy to note that, all treatments had the same added amount of sugar.

\section{Minerals content:}

Minerals content of ingredients of Talbeena given in table (3). Concerning flour type, it could be observed that, $\mathrm{Na}, \mathrm{K}, \mathrm{Ca}$ and $\mathrm{Zn}$ content was higher in barley flour than malt, while there were non significant differences in the content of Fe between two flours. Differences between flour types may be due to malting process effects. Soaking in Water (steeping) leads to loss of water-soluble components especially minerals. In this concern (Tamime et al, 1997) detected lower contents in three barley varieties for $\mathrm{Na}(6.5-7.5 \mathrm{mg} \backslash 100 \mathrm{~g})$, Ca $(46.5-47.5 \mathrm{mg} / 100 \mathrm{~g}), \mathrm{P}$ (388- 406 $\mathrm{mg} \backslash 100 \mathrm{~g})$, and $\mathrm{Zn}(1.97-2.87 \mathrm{mgl} 100 \mathrm{~g})$. However, higher $\mathrm{K}$ content (486-550 $\mathrm{mg} / 100 \mathrm{~g})$ was detected, and nearly similar Fe content $(2.34-3.17 \mathrm{mg} \backslash 100 \mathrm{~g})$, compared with these results.

Data presented also in table (3) data illustrated high significant differences in all minerals content between the skimmed and full cream milk. skimmed milk was superior in its content of all minerals than full cream milk, except $\mathrm{Fe}$, which reflected higher nutritional value related to the addition of skimmed milk. 
J. Agric. Sci. Mansoura Univ., 33(11), November, 2008

T2-3 


\section{Minerals contents of Talbeena :}

Minerals content of Talbeena is given in table (4). Among flour types (control, with skimmed milk, and with full cream milk) there were non significant differences in $\mathrm{Na}, \mathrm{P}$, and $\mathrm{Fe}$ contents. On the contrary, differences in $\mathrm{K}$, and $\mathrm{Ca}$ content was high significant, also, $\mathrm{Zn}$ showed significant difference. Treatments showed more comparative differences which is due to milk types. It could be stated that, Talbeena treatments with full cream milk were much higher in Fe content. Meanwhile, skimmed milk treatments excelled in $\mathrm{Na}, \mathrm{K}, \mathrm{Ca}, \mathrm{P}$, and $\mathrm{Zn}$ content. Control treatments were distinguished with lesser nutritional value. Barley flour was more nutritional than malt flour.

Table (4): Minerals contents of Talbeena ( $\mathrm{mg} / 100 \mathrm{ml})$ :

\begin{tabular}{|c|c|c|c|c|c|c|c|c|c|}
\hline \multirow{2}{*}{\multicolumn{2}{|c|}{\begin{tabular}{|l|} 
Component \\
Treatment
\end{tabular}}} & \multicolumn{6}{|c|}{ Macro Elements } & \multicolumn{2}{|c|}{ Micro Elements } \\
\hline & & $\mathrm{Na}$ & K & $\mathrm{Ca}$ & $\mathbf{P}$ & $\mathrm{Na} / \mathrm{K}$ & $\mathrm{Ca} / \mathrm{P}$ & $\mathrm{Fe}$ & $\mathrm{Zn}$ \\
\hline \multirow{3}{*}{ 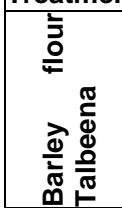 } & 1 & \begin{tabular}{|c|c|c|}
0.59 \\
\pm 0.04
\end{tabular}${ }^{c}$ & $\begin{array}{l}15.55 \\
\pm 0.12\end{array}$ & $\begin{array}{c}3.31 \\
\pm 0.06\end{array}$ & $\begin{array}{l}12.97 \\
\pm 0.14\end{array}$ & \begin{tabular}{|c|}
0.038 \\
\pm 0.002 \\
\end{tabular} & \begin{tabular}{|c|c}
0.256 \\
\pm 0.008
\end{tabular} & \begin{tabular}{|c|}
0.093 \\
\pm 0.001 \\
\end{tabular} & $\left.\begin{array}{c}0.195 \\
\pm 0.002\end{array}\right|^{c}$ \\
\hline & 2 & \begin{tabular}{|l|}
40.28 \\
\pm 0.86
\end{tabular} & $\begin{array}{c}130.24 \\
\pm 2.77\end{array}{ }^{\mathrm{a}}$ & \begin{tabular}{l|}
127.7 \\
\pm 3.82
\end{tabular} & $\begin{array}{c}110.73 \\
\pm 3.16\end{array}$ & \begin{tabular}{|c|}
0.309 \\
\pm 0.008 \\
\end{tabular} & & \begin{tabular}{|c|}
0.159 \\
\pm 0.002 \\
\end{tabular} & $\begin{array}{c}0.781 \\
\pm 0.013\end{array}$ \\
\hline & 3 & \begin{tabular}{|l|l|}
26.66 \\
\pm 1.17 \\
\end{tabular} & $\begin{array}{c}112.69 \\
\pm 0.18\end{array}$ & $\begin{array}{l}0.05 \\
\pm 0.61\end{array}$ & $\begin{array}{l}67.79 \\
\pm 1.29 \\
\end{array}$ & \begin{tabular}{|c|}
0.237 \\
\pm 0.011 \\
\end{tabular} & \begin{tabular}{|c|}
1.406 \\
\pm 0.038
\end{tabular} & \begin{tabular}{|c|}
0.344 \\
\pm 0.009 \\
\end{tabular} & \\
\hline \multicolumn{2}{|c|}{$\begin{array}{l}\text { LSD / Sign (P } \leq \\
0.05)\end{array}$} & 2.66 & 1.47 & 3.53 & 4.74 & 0.02 & 0.07 & 0.02 & 0.03 \\
\hline \multirow{3}{*}{ 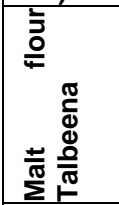 } & 4 & \begin{tabular}{|c|c|c|}
0.49 & $c$ \\
\pm 0.07 & \\
\end{tabular} & \begin{tabular}{l|l}
13.12 \\
\pm 0.12
\end{tabular}${ }^{\mathrm{c}}$ & \begin{tabular}{c|}
2.66 \\
\pm 0.04
\end{tabular} & \begin{tabular}{l|}
12.32 \\
\pm 0.14
\end{tabular} & \begin{tabular}{|c|}
0.038 \\
\pm 0.006 \\
\end{tabular} & \begin{tabular}{|c|}
0.216 \\
\pm 0.001 \\
\end{tabular} & \begin{tabular}{|c|}
0.093 \\
\pm 0.002 \\
\end{tabular} & \\
\hline & 5 & $\begin{array}{l}40.19 \\
\pm 0.89\end{array}$ & $\begin{array}{c}127.82 \\
\pm 0.77\end{array}$ & $\begin{array}{c}127.04 \\
\pm 1.81\end{array}$ & $\begin{array}{l}110.07 \\
\pm 2.16 \\
\end{array}$ & \begin{tabular}{|c|}
0.315 \\
\pm 0.009 \\
\end{tabular} & $\begin{array}{c}1.154 \\
\pm 0.001\end{array}$ & \begin{tabular}{|c|}
0.159 \\
\pm 0.002 \\
\end{tabular} & $\mathrm{~b} \mid \begin{array}{c}0.809 \\
\pm 0.011\end{array}{ }^{\mathrm{a}}$ \\
\hline & 6 & \begin{tabular}{|l|l}
26.57 \\
\pm 1.12
\end{tabular} & $\begin{array}{c}110.27 \\
\pm 0.18\end{array}$ & $\begin{array}{l}94.61 \\
\pm 0.62\end{array}$ & $\begin{array}{l}67.14 \\
\pm 1.94\end{array}$ & $\begin{array}{c}0.241 \\
\pm 0.011\end{array}$ & \begin{tabular}{|c|}
1.409 \\
\pm 0.032
\end{tabular} & \begin{tabular}{|c|}
0.345 \\
\pm 0.008 \\
\end{tabular} & $\left|\begin{array}{c}0.451 \\
\pm 0.007\end{array}\right| \mathrm{b}$ \\
\hline \multicolumn{2}{|c|}{$\begin{array}{l}\text { LSD / Sign (P S } \\
0.05)\end{array}$} & 2.65 & 1.48 & 3.51 & 4.55 & 0.03 & 0.06 & 0.03 & 0.04 \\
\hline \multirow{2}{*}{\multicolumn{2}{|c|}{\begin{tabular}{|l} 
Type of flour \\
Type of liquid
\end{tabular}}} & Ns & 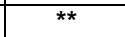 & $\hbar \star$ & Ns & & 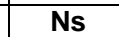 & Ns & \\
\hline & & 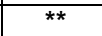 & ** & 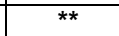 & $\star \star *$ & & & k* & \\
\hline \multicolumn{2}{|c|}{ Interaction } & Ns & ** & 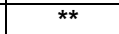 & & $\bar{x}$ & & Ns & \\
\hline
\end{tabular}

Values in the same column with different letters (a, b, $c$ and d) are significantly different $(P \leq 0.05)$.

All values are means of three replicates \pm SD.

1 = control barley flour (made with water).

2 = barley flour with Skimmed milk.

$4=$ control malt flour (made with water)

$3=$ barley flour with full cream milk.

$5=$ malt flour with Skimmed milk.

$6=$ malt flour with full cream milk.

\section{Insoluble, Soluble and Total $\beta$-Glucan contents of Talbeena :}

The $\beta$-glucan content (insoluble, soluble \& total) is given in table (5). It could be observed that, the differences between barley and malt flours $\beta$-Glucan contents were high significant.

There was a noticeable decrease from $6.093 \%$ in barley flour, to $4.432 \%$ in malt flour in tsotal $\beta$-glucan,. In the same concern, insoluble $\beta$ Glucan was obviously higher in barley flour than malt flour. In contrast, soluble $\beta$-Glucan was higher in malt flour than barley flour. This is attributed mainly to the activity of $\beta$-Glucanase in $\beta$-Glucan degradation during malting process, which causes $\beta$-Glucan to break down, resulting in molecules that are more soluble and lesser total content. Data presented in table (5) could 
be read as percentage of solubility as follow, the highest $\beta$-Glucan solubility \% was recorded in malt flour $68.43 \%$, while barley flour was $33.97 \%$. Insoluble $\beta$-Glucan showed higher percentage in barley flour $66.03 \%$ than malt flour $31.57 \%$. Concerning $\beta$-Glucan content in Talbeena treatments, data is shown in the second part of the same table. Similar trends were noticed. The similar solubility percentages of both raw flour and product might be due to the reversible effect of heating on $\beta$-Glucan physical properties (Dawkins and Nnanna, 1995). Differences in Solubility of $\beta$ Glucan between the two flours could be attributed to due to the hydrolysis during malting. This was in match with (Andersson et al, 2004) who reported that, the whole-meals fractions of barley content of $\beta$-glucan ranged between $4.2-5.8 \%$, the water-extractability of $\beta$-glucan was also $55-63 \%$.

Table (5): Insoluble, Soluble \& Total $\beta$-Glucan contents of Talbeena $(\mathrm{gm} / 100 \mathrm{ml})$ :-

\begin{tabular}{|c|c|c|c|c|c|c|c|c|c|c|c|}
\hline \multicolumn{2}{|l|}{ Components } & \multicolumn{2}{|c|}{$\begin{array}{c}\text { Insoluble } \\
\beta \text {-Glucan }\end{array}$} & \multicolumn{2}{|c|}{$\begin{array}{l}\text { Soluble } \\
\beta \text {-Glucan }\end{array}$} & \multicolumn{2}{|c|}{$\begin{array}{c}\text { Total } \\
\beta \text {-Glucan }\end{array}$} & \multicolumn{2}{|c|}{$\begin{array}{c}\% \text { Insoluble } \\
\beta \text {-Glucan }\end{array}$} & \multicolumn{2}{|c|}{$\begin{array}{c}\% \text { Soluble } \\
\beta \text {-Glucan }\end{array}$} \\
\hline \multirow{2}{*}{ * Raw } & Barley flour & $\begin{array}{c}4.023 \\
\pm 0.097\end{array}$ & $\mathrm{a}$ & $\begin{array}{c}2.069 \\
\pm 0.007\end{array}$ & $\mathrm{~b}$ & $\begin{array}{c}6.093 \\
\pm 0.104\end{array}$ & $\mathrm{a}$ & $\begin{array}{l}66.03 \\
\pm 0.47\end{array}$ & $\mathrm{a}$ & $\begin{array}{l}33.97 \\
\pm 0.47\end{array}$ & $\mathrm{~b}$ \\
\hline & Malt flour & $\begin{array}{c}1.399 \\
\pm 0.206\end{array}$ & $\mathrm{~b}$ & $\begin{array}{c}3.033 \\
\pm 0.049\end{array}$ & $\mathrm{a}$ & $\begin{array}{c}4.432 \\
\pm 0.186\end{array}$ & $\mathrm{~b}$ & $\begin{array}{l}31.57 \\
\pm 1.25 \\
\end{array}$ & $\mathrm{~b}$ & $\begin{array}{l}68.43 \\
\pm 1.25\end{array}$ & $\mathrm{a}$ \\
\hline \multicolumn{2}{|c|}{ LSD / Sign $(P \leq 0.05)$} & \multicolumn{2}{|c|}{$0.278^{\star \star}$} & \multicolumn{2}{|l|}{$0.061^{\star \star}$} & \multicolumn{2}{|c|}{$0.261^{\star \star}$} & \multicolumn{2}{|c|}{$4.02^{\star \star}$} & \multicolumn{2}{|c|}{$4.02^{\star \star}$} \\
\hline \multirow{2}{*}{-Treatments } & Barley flour & \begin{tabular}{c|}
0.161 \\
\pm 0.004 \\
\end{tabular} & $\mathrm{a}$ & $\begin{array}{c}0.083 \\
\pm 0.001 \\
\end{array}$ & $\mathrm{~b}$ & $\begin{array}{c}0.244 \\
\pm 0.004 \\
\end{array}$ & $\mathrm{a}$ & $\begin{array}{l}65.98 \\
\pm 0.47 \\
\end{array}$ & $\mathrm{a}$ & $\begin{array}{l}34.01 \\
\pm 0.47 \\
\end{array}$ & $\mathrm{~b}$ \\
\hline & Malt flour & $\begin{array}{c}0.056 \\
\pm 0.008\end{array}$ & $\mathrm{~b}$ & $\begin{array}{c}0.121 \\
\pm 0.002\end{array}$ & $a$ & $\begin{array}{c}0.177 \\
\pm 0.007\end{array}$ & $\mathrm{~b}$ & $\begin{array}{l}31.64 \\
\pm 1.25\end{array}$ & $\mathrm{~b}$ & $\begin{array}{l}-68.36 \\
\pm 1.25\end{array}$ & $a$ \\
\hline \multicolumn{2}{|c|}{ LSD / Sign $(P \leq 0.05)$} & \multicolumn{2}{|c|}{$0.011^{\star \star}$} & \multicolumn{2}{|l|}{$0.003^{\star \star}$} & \multicolumn{2}{|c|}{$0.011^{\star \star}$} & \multicolumn{2}{|c|}{$4.02^{\star *}$} & \multicolumn{2}{|c|}{$4.02^{\star \star}$} \\
\hline
\end{tabular}

Values in the same column with different letters (a \& b) are significantly different (P $\leq$ 0.05).

* All values are means of four replicates \pm SD on dry weight basis.

- All values are means of four replicates $\pm S D(\mathrm{gm} / 100 \mathrm{ml})$.

Also, these findings are in agreement with (Bathgate et al, 1974) who suggested that the initial release of $\beta$-glucans was affected by endo- $\beta$ - (1, $3)$-glucanases, which are found in steeped barley. Carboxypeptidases ( $\beta$ glucan solubilases) are also involved in the release of $\beta$-glucans (Bamforth, 1981). Since $\beta$-glucans are associated with proteins and phospholipids proteases and phospholipidases may also be involved in the release of $\beta$ glucans from the endosperm cell walls (Palmer, 1975). That explains why the United States Food and Drug Administration (FDA) authorized use of a health claim for the role of $\beta$-Glucan soluble fiber from barley in reducing the risk of coronary heart diseases, while didn't approve malt products to be eligible for the claim (FDA, 2006).

Concerning malting in the recent study, it is worthy note that the chemical composition of $\beta$-glucan from partially modified (2-day germination) malt is similar to that of $\beta$-glucan extracted from barley, but the physical properties and the enzyme susceptibilities are not similar. $\beta$-glucan extracted from malt germinated for 2 days is more viscous and "retrogrades" from solution to gels or precipitates more readily, because of prolonged degradation of macromolecules, while, the extended germination time 
reduces the content of $\beta$-glucans in malt, but this leads to higher levels of soluble proteins, as demonstrated by (Bathgate et al., 1974).

There has to be $0.75 \mathrm{~g}$ of $\beta$-glucan per portion in food product to reach the level recommended by FDA to achieve the health effect, which was $3 \mathrm{~g}$ per day. Beverage model in this study contained $0.244 \mathrm{~g} / 100 \mathrm{ml}$ in barley flour Talbeena, while, malt flour Talbeena contained $0.177 \mathrm{~g} / 100 \mathrm{ml}$. which means that, it needs two servings $(200 \mathrm{ml})$ of barley flour Talbeena to cover the required amount to have the health claim in compliance of the FDA limits.

Viscosity measurement of Talbeena:

Data given in table (6) show the measured viscosity of Talbeena treatments. There were large variation between the preparations. Generally, viscosity of barley flour treatments were extremely higher than malt treatments.

Table (6): Viscosity of Talbeena drink treatments:

\begin{tabular}{|c|c|c|c|c|c|}
\hline \multirow{2}{*}{\multicolumn{2}{|c|}{\begin{tabular}{|l} 
Characteristics \\
Treatments
\end{tabular}}} & \multicolumn{2}{|c|}{ Bingham } & \multicolumn{2}{|c|}{ Power law } \\
\hline & & $\begin{array}{c}\text { Plastic viscosity } \\
\text { (mpas) }\end{array}$ & $\begin{array}{c}\text { Yield stress } \\
\left(\mathrm{Ncm}^{-2}\right)\end{array}$ & $\begin{array}{l}\text { Consistency } \\
\text { index (mpas) }\end{array}$ & Flow index \\
\hline \multirow{3}{*}{ 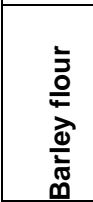 } & 1 & $\begin{array}{l}49.00 \\
\pm 1.56\end{array}$ & $\begin{array}{l}28.75 \\
\pm 8.84\end{array}$ & $\begin{array}{c}466.60 \\
\pm 177.20 \\
\end{array}$ & $\begin{array}{c}0.63 \\
\pm 0.06\end{array}$ \\
\hline & 2 & $\begin{array}{l}-1.45 \\
\pm 5.73\end{array}$ & $\begin{array}{l}10.96 \\
\pm 3.03\end{array}$ & $\begin{array}{r}152.90 \\
\pm 38.18\end{array}$ & $\begin{array}{c}0.76 \\
\pm 0.05\end{array}$ \\
\hline & 3 & $\begin{array}{l} \pm 0.10 \\
24.55 \\
\pm 1.77\end{array}$ & $\begin{array}{l}10.48 \\
\pm 2.72\end{array}$ & $\begin{array}{r}+154.30 \\
\pm 46.67 \\
\end{array}$ & $\begin{array}{c}0.72 \\
\pm 0.02 \\
\end{array}$ \\
\hline \multirow{3}{*}{ 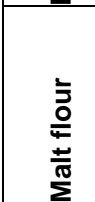 } & 4 & $\begin{array}{c}4.90 \\
\pm 0.08\end{array}$ & $\begin{array}{c}0.00 \\
\pm 0.00\end{array}$ & $\begin{array}{c}1.96 \\
\pm 0.02\end{array}$ & $\begin{array}{c}1.19 \\
\pm 0.01\end{array}$ \\
\hline & 5 & $\begin{array}{l}13.75 \\
\pm 1.77\end{array}$ & $\begin{array}{c}4.80 \\
\pm 1.81\end{array}$ & $\begin{array}{c}54.10 \\
\pm 20.93\end{array}$ & $\begin{array}{c}0.78 \\
\pm 0.08\end{array}$ \\
\hline & 6 & $\begin{array}{c}7.73 \\
\pm 0.49\end{array}$ & $\begin{array}{c}0.94 \\
\pm 0.75\end{array}$ & $\begin{array}{l}17.20 \\
\pm 9.76\end{array}$ & $\begin{array}{c}0.88 \\
\pm 0.12\end{array}$ \\
\hline
\end{tabular}

1 = control barley flour (made with water). $\quad 4$ = control malt flour (made with water).

2 = barley flour with Skimmed milk.

3 = barley flour with full cream milk.

$5=$ malt flour with Skimmed milk.

In barley flour treatments, the viscosity decreased remarkably with the addition of skimmed milk and full cream milk. In contrary, malt flour treatments showed increased viscosity with the addition of milk types. To further understanding the measured viscosity of tested Talbeena preparations, we should put in consideration the effect of two factors: flour type (barley, malt), and liquid type (water, skimmed milk, and full cream milk) in treatments. The noticed difference between barley and malt flours is in $\beta$ glucan content. The link between $\beta$-glucan content, which forms gel solutions and affect the relative viscosity. In addition, molecular weight of $\beta$-glucan is key factor in this respect, low molecular weight $\beta$-glucan produced from malting or heat treatments gave lower viscous solutions than high molecular weight $\beta$-glucan in barley flour. That explains the less viscous solution of malt treatments especially control compared with the control of barley treatments. The main carbohydrates content in barley flour are starch which gelatinized by heating in solution, and $\beta$-glucans which also make gel solution by heating. The degradation of $\beta$-glucans during malting lead to lower molecular weight $\beta$-glucans ( Jin et al, 2004). In beverages, the high molecular weight $\beta$ glucans works as more effective thickeners than low molecular weight $\beta$ - 
glucans as a function of concentration (Lyly, 2006). However, it is difficult to separate the pure effect of $\beta$-glucan viscosity from other exist hydrocolloids, as flour contain proteins, starch and other minor carbohydrates, on the measured viscosity. Partially, it could be correlated to the recorded differences in $\beta$-glucan content of flours. The viscosity of $\beta$-glucan temporarily decrease with increased temperature (Dawkins and Nnanna, 1995), but the effect of temperature on viscosity of $\beta$-glucan is reversible. Similarly, Burkus and Temelli (2005) observed reversible drop in viscosity with temperature in laboratory prepared barley $\beta$-glucan solutions. Thus, it is possible to use hot beverages as a carrier of health benefits of barley $\beta$ glucan without negatively affecting its properties by processing, as the product would have decreased temperature during drinking.

It is important to remember that health benefits of barley $\beta$-glucan are linked to its viscosity. As the higher viscous $\beta$-glucan gel, the higher cholesterol blood glucose lowering effectiveness (Wood et al, 2000). Therefore, instrumental viscosity is crucial for achieving the healthy effects claimed to barley products. Thus, we can state that, Talbeena made from barley flour had the health functions claimed for barley $\beta$-glucan.

Sensory evaluation of Talbeena:

From table (7), it is evident that, barley flour Talbeena was better than that of malt flour. Concerning color, appearance and .Color in Malt flour characterized with darker color that is due to browning reactions during drying step of malt .Malt flour was higher than barley flour Talbeena in taste, mouth feeling and odor.

Table (7): Sensory evaluation of Talbeena:

\begin{tabular}{|c|c|c|c|c|c|c|c|c|c|c|c|c|c|}
\hline \multicolumn{2}{|c|}{\begin{tabular}{|l|} 
Characteristics \\
Treatments \\
\end{tabular}} & \multicolumn{2}{|c|}{$\begin{array}{l}\text { Color } \\
(20)\end{array}$} & \multicolumn{2}{|c|}{$\begin{array}{l}\text { Odor } \\
(20)\end{array}$} & \multicolumn{2}{|c|}{$\begin{array}{l}\text { Taste } \\
(20)\end{array}$} & \multicolumn{2}{|c|}{$\begin{array}{l}\text { Mouth } \\
\text { feel (20) }\end{array}$} & \multicolumn{2}{|c|}{$\begin{array}{c}\text { Appearanc } \\
\text { e } \\
(20)\end{array}$} & \multicolumn{2}{|c|}{$\begin{array}{l}\text { Overall } \\
(100\end{array}$} \\
\hline \multirow{3}{*}{$\begin{array}{l}\frac{3}{3} \\
\frac{0}{L} \\
\frac{\partial}{2} \\
\frac{\pi}{\pi}\end{array}$} & 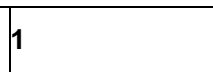 & \begin{tabular}{|l|}
13.00 \\
\pm 1.02 \\
\end{tabular} & $\mathrm{c}$ & \begin{tabular}{|l|}
13.42 \\
\pm 1.27 \\
\end{tabular} & c & \begin{tabular}{l|}
12.00 \\
\pm 1.41
\end{tabular} & c & \begin{tabular}{|l|}
12.43 \\
\pm 1.87 \\
\end{tabular} & $\mathrm{c}$ & \begin{tabular}{|l|}
13.57 \\
\pm 1.71 \\
\end{tabular} & ${ }^{c}$ & $\begin{array}{l}64.42 \\
\pm 2.99\end{array}$ & c \\
\hline & 2 & \begin{tabular}{|l|}
16.71 \\
\pm 1.38 \\
\end{tabular} & $\mathrm{~b}$ & $\begin{array}{l}15.28 \\
\pm 1.11\end{array}$ & $\mathrm{~b}$ & $\begin{array}{l}14.50 \\
\pm 1.71\end{array}$ & b & $\begin{array}{l}16.28 \\
\pm 1.75\end{array}$ & $\mathrm{~b}$ & $\begin{array}{l}16.43 \\
\pm 1.83\end{array}$ & $\mathrm{~b}$ & $\begin{array}{l}79.22 \\
\pm 3.33\end{array}$ & $\mathrm{~b}$ \\
\hline & 3 & $\begin{array}{l}18.50 \\
\pm 0.96\end{array}$ & a & $\begin{array}{l}17.85 \\
\pm 1.35\end{array}$ & a & $\begin{array}{r}16.85 \\
\pm 1.21\end{array}$ & a & $\begin{array}{l}18.43 \\
\pm 1.97\end{array}$ & $\mathrm{a}$ & $\begin{array}{l}18.71 \\
\pm 1.11\end{array}$ & $\mathrm{a}$ & $\begin{array}{l}90.36 \\
\pm 3.81\end{array}$ & a \\
\hline LSD / & Sign $(P \leq 0.05)$ & 1.27 & & 1.41 & & 1.82 & & 2.03 & & 1.43 & & 5.6 & \\
\hline \multirow{3}{*}{$\begin{array}{l}\overline{\bar{z}} \\
\stackrel{0}{\underline{L}} \\
\frac{ \pm}{\pi} \\
\Sigma\end{array}$} & 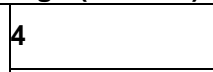 & \begin{tabular}{|l|}
12.93 \\
\pm 1.36 \\
\end{tabular} & $\mathrm{c}$ & \begin{tabular}{|l|}
13.78 \\
\pm 0.96 \\
\end{tabular} & c & \begin{tabular}{|l|}
13.78 \\
\pm 1.23 \\
\end{tabular} & c & \begin{tabular}{|l|}
14.07 \\
\pm 1.31 \\
\end{tabular} & c & \begin{tabular}{|l|}
13.14 \\
\pm 1.46 \\
\end{tabular} & $\mathrm{c}^{\mathrm{c}}$ & $\begin{array}{l}67.71 \\
\pm 4.61 \\
\end{array}$ & c \\
\hline & 5 & $\begin{array}{l}15.50 \\
\pm 1.97 \\
\end{array}$ & b & $\begin{array}{l}15.64 \\
\pm 1.05 \\
\end{array}$ & $\mathrm{~b}$ & $\begin{array}{l}15.86 \\
\pm 1.03 \\
\end{array}$ & b & $\begin{array}{l}15.14 \\
\pm 1.63 \\
\end{array}$ & $\mathrm{~b}$ & $\begin{array}{l}15.71 \\
\pm 1.65 \\
\end{array}$ & $\mathrm{~b}$ & $\begin{array}{l}77.86 \\
\pm 3.61 \\
\end{array}$ & b \\
\hline & 6 & \begin{tabular}{|l|}
17.36 \\
\pm 1.49 \\
\end{tabular} & a & $\begin{array}{r}18.42 \\
\pm 1.13 \\
\end{array}$ & $\mathrm{a}$ & \begin{tabular}{|l|}
18.28 \\
\pm 1.11 \\
\end{tabular} & a & \begin{tabular}{|l|}
18.71 \\
\pm 1.13 \\
\end{tabular} & $a$ & \begin{tabular}{r|}
17.92 \\
\pm 1.83 \\
\end{tabular} & $\mathrm{a}$ & $\begin{array}{l}90.71 \\
\pm 3.46 \\
\end{array}$ & $\mathrm{a}$ \\
\hline \multicolumn{2}{|c|}{\begin{tabular}{|l|} 
LSD / Sign $(P \leq 0.05)$ \\
Type of flour
\end{tabular}} & \multirow{2}{*}{\multicolumn{2}{|c|}{\begin{tabular}{|l|}
1.84 \\
$\mathrm{Ns}$
\end{tabular}}} & \multicolumn{2}{|l|}{1.65} & \multicolumn{2}{|l|}{1.26} & \multicolumn{2}{|l|}{1.64} & \multicolumn{2}{|c|}{1.59} & \multicolumn{2}{|c|}{5.69} \\
\hline \multirow{2}{*}{\multicolumn{2}{|c|}{\begin{tabular}{|l|} 
Type of flour \\
Type of liquid \\
\end{tabular}}} & \multirow{2}{*}{\multicolumn{2}{|c|}{ ** }} & \multirow{2}{*}{\multicolumn{2}{|c|}{ Ns }} & \multirow{2}{*}{\multicolumn{2}{|c|}{${ }^{\star \star}$}} & \multirow{2}{*}{\multicolumn{2}{|c|}{$\begin{array}{l}\text { Ns } \\
\star \star \star\end{array}$}} & \multirow{2}{*}{\multicolumn{2}{|c|}{$\begin{array}{l}\text { Ns } \\
* *\end{array}$}} & \multirow{2}{*}{\multicolumn{2}{|c|}{$\frac{\text { NS }}{* *}$}} \\
\hline & & & & & & & & & & & & & \\
\hline \multicolumn{2}{|c|}{ Type of flour liquid } & \multicolumn{2}{|l|}{ Ns } & \multicolumn{2}{|l|}{ Ns } & \multicolumn{2}{|l|}{ * } & \multicolumn{2}{|l|}{ Ns } & \multicolumn{2}{|l|}{ Ns } & \multicolumn{2}{|c|}{ Ns } \\
\hline
\end{tabular}

Values in the same column with different letters (a, b, $c$ and $d)$ are significantly different $(P \leq 0.05)$.

All values are means of 15 replicates $\pm S$ on dry weight basis $D$.

$1=$ control barley flour (made with water). $\quad 4=$ control malt flour (made with water).

2 = barley flour with Skimmed milk.

$5=$ malt flour with Skimmed milk.

$\mathbf{3}=$ barley flour with full cream milk.

$6=$ malt flour with full cream milk. 
This could be explained by considering the effect of malting and drying processes on the formation and release of aroma compounds. In all treatments overall acceptability was significantly improved by the addition of full cream milk, due to its high content of fatty acids and other components responsible for aroma, followed by skimmed milk.

\section{REFERENCES}

A.O.A.C. (2000). Official Methods of Analysis of AOAC International. (17 th ed.) by Horwitz, W. Suite 500, 481 North Fredric Avenue Gaithersburg, Maryland 20877 - 2417, USA.

Aly, M. E. (1997). Malt extract for enhancing flavour development of ultrafiltered domiati cheese. J. Food Chemistry, 59(1): 127- 133.

Andersson, A.; Armo, E.; Grangeon, E.; Fredriksson, H.; Andersson, R. and Åman, P. (2004). Molecular weight and structure of $(1 \rightarrow 3)(1 \rightarrow 4)-\beta-d-$ glucans in dough and bread made from hull-less barley milling fractions. J. Cereal Science, 40: 195- 204.

Assem, N. H.; El-Mottaleb, M. and Attia, A. (2002). Effect of germination and gelatinization of hulless barley on produced balady bread. Pp 33-48. Proceeding of food quality conference, Cairo 10-13 october, 2002.

Bamforth, C. W. (1981). J. Inst. Brew., 87:276. C.F. Madacsi, J. P.; Parrish, F. W.; and Roberts, E. J. (1983). Nonenzymic Method for Determination of Beta-Glucan in the Presence of Starch. The American Society of Brewing Chemists, Vol. 41 No. 4: 161-162.

Bathgate, G. N.; Palmer, G. H. and Wilson, G. (1974). The action of endo- $\beta$ glucanases on barley and malt $\beta$-glucans. J. Inst. Brew, 80: 278- 285.

Behall, K.M.; Scholfield, D.J. and Hallfrisch, J. (2004). Diets containing barley significantly reduce lipids in mildly hypercholesterolemic men and women. American Journal of Clinical Nutrition, 80: 1185- 1193.

Burkus, Z.; and Temelli, F. (2005). Rheological properties of barley b-glucan. Carbohydrate Polymers, (59): 459- 465.

Cavallero, A.; Empilli, S.; Brighenti, F., and Stanca, A. M. (2002). High $(1 \rightarrow 3,1 \rightarrow 4)$ - $\beta$-glucan barley fractions in bread making and their effects on human glycemic response. J. Cereal Science, 36: 59- 66.

Dawkins, N. L. and Nnanna, I. A. (1995). Studies on oat gum [(1-3, 1-4) $\beta$-Dglucan]: Composition, molecular weight estimation and rheological properties. Food Hydrocolloids, 9: 1-7.

Eckles, C. H.; Combs, W. B. and Macy, H. (1951). Milk and Milk Products. fourth edition. published by TATA MCGRAW-HILL Publishing Company LTD. Bombay, New Delhi.

Erkan, Y.; Celik, S.; Berna B. and Koksel, H. (2006). A new approach for the utilization of barley in food products: Barley tarhana. J. Food Chemistry, 97: 12- 18.

FDA (Food and Drug Administration). (2006). FDA Finalizes Health Claim Associating Consumption of Barley Products with Reduction of Risk of Coronary Heart Disease.

http://www.fda.gov/ohrms/dockets/98FR/04p-0512-nfr0001.pdf 
Gaosong, J. and Vasanthan, T. (2000). Effect of extrusion cooking on the primary structure and water solubility of $\beta$-glucan from regular and waxy barley. Cereal Chemistry, 77. (3): 396- 400.

Hesse, P. R. (1971). Soil phosphorus: its measurements and its uptake by plants. Aust. J. Soil. Res., 35: 227- 239.

Ibn Al Qayyim Al Jawziyyah. (1957). al Tibb al Nabawi. ALfaisal puplications. Egypt. In Arabic.

Jackson, M.L. (1967). Soil chemical analysis. Prentice-Hall of India, New Delhi.

Jin, Yu-Lai ; Speers, R. A.; Paulson, A. T. and Stewart, R. J.(2004). Barley bglucans and their degradation during malting and brewing. MBAA TQ Vol. 41, No. (3) pp. 231-240.

Lyly, M. (2006). Added $\beta$-glucan as a source of fiber for consumers. Espoo. VTT Publications 594.96 p. + app. 50 p.

Lyly, M.; Salmenkallio-Marttila, M., Suortti, T., Autio, K., Poutanen, K. and Lähteenmäki, L. (2004). The sensory characteristics and rheological properties of soups containing oat and barley $\beta$-glucan before and after freezing. Lebensmittel-Wissenschaft und Technologie 37, 749.761.

Madacsi, J. P.; Parrish, F. W.; and Roberts, E. J. (1983). Nonenzymic Method for Determination of Beta-Glucan in the Presence of Starch. The American Society of Brewing Chemists, Vol. 41 No. 4: 161-162.

Niva, M. (2007).All foods affect health': Understandings of functional foods and healthy eating among health-oriented Finns (Research report). Appetite 48 (2007) 384-393.

Nyima, T. (2005). Food Preparation from Hull-less Barley in Tibet. Pp115120, Food Barley: Importance, Uses and Local Knowledge. Proceedings of the International Workshop on Food Barley Improvement, 14-17 January 2002, Hammamet, Tunisia. (ICARDA, Aleppo, Syria, $x+156 \mathrm{pp}$. En).

Palmer, G.H. (1975). Influence of endosperm structure on extract development.Proc. Am. Soc. Brew. Chem., 33: 174- 180.

Puspa, R. S.; Connie, M. W. and April, C. M. (1994). Mineral bioavailability in rates from intrinsically labeled whole- wheat flour of various phytate levels. J. Agric. Food Chem., Vol. 42, NO. 11: 2531-2535.

Tamime, A.Y.; Muir, D.D.; Barclay, M.N.I.; Khaskheli, M. and Mcnulty, D. (1997). Laboratory-made Kishk from wheat, oat, and barley: production and comparison of chemical and nutritional composition of burghul. Food research international, 30 (5): 311- 317.

WHO (World Health Organization). (2003). Diet, nutrition and the prevention of chronic diseases. Report of a joint WHO / FAO expert consultation. WHO Technical Report Series 916. Geneva.

Wood, P.J.; Beer, M.U. and Butler, G. (2000). Evaluation of role of concentration and molecular weight of oat $\beta$-glucan in determining effect of viscosity on plasma glucose and insulin following an oral glucose load. British Journal of Nutrition, 84: 19- 23. 
Wood, P.J.; Beer, M.U. and Butler, G. (2000). Evaluation of role of concentration and molecular weight of oat $\beta$-glucan in determining effect of viscosity on plasma glucose and insulin following an oral glucose load. British Journal of Nutrition, 84: 19- 23.

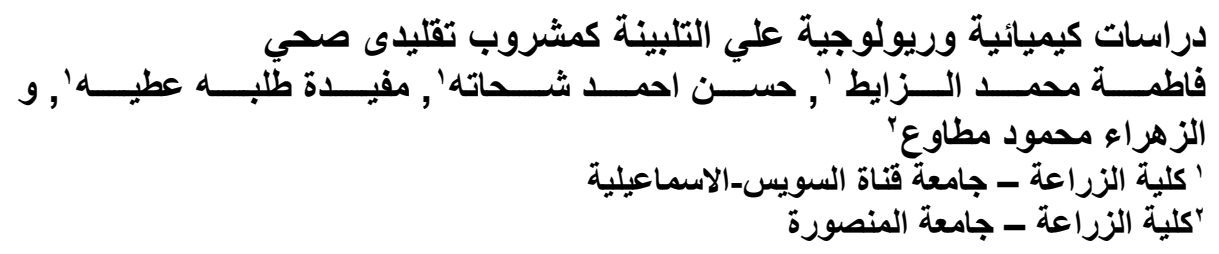

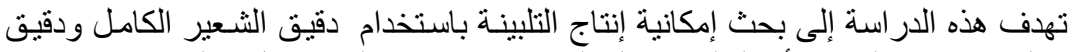

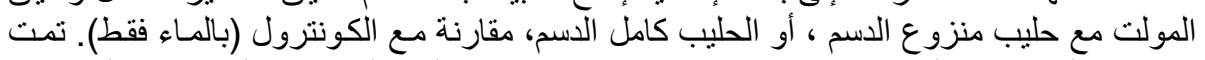

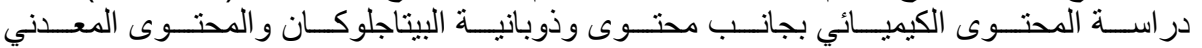

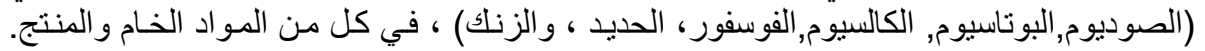

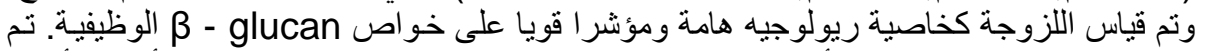

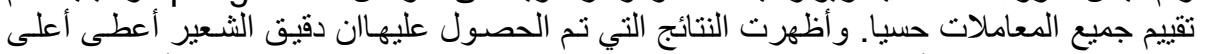

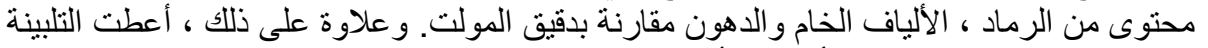

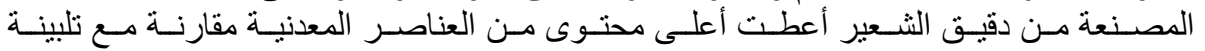

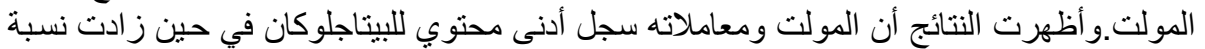

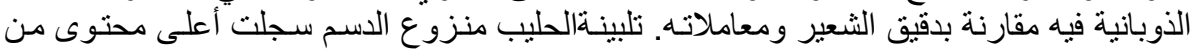

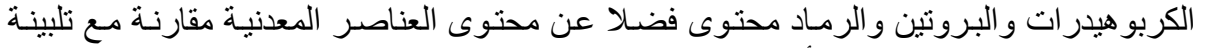

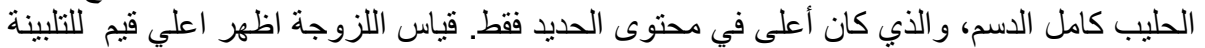

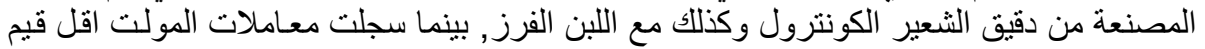

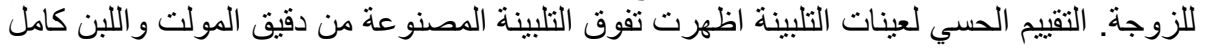

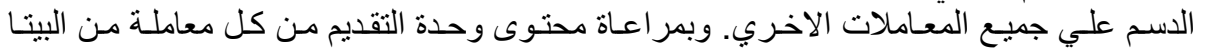

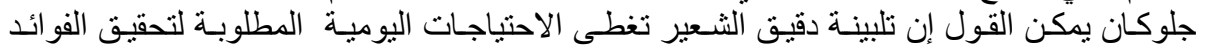
الصحية المنسوبة لبيتاجلوكان الثعير. 
J. Agric. Sci. Mansoura Univ., 33(11), November, 2008 
Table (2): Chemical composition of Talbeena $(\mathrm{gm} / 100 \mathrm{ml})$ on dry weight basis:

\begin{tabular}{|c|c|c|c|c|c|c|c|c|c|c|c|c|c|c|c|}
\hline \multicolumn{2}{|c|}{$\begin{array}{l}\text { Components } \\
\text { Treatments } \\
\end{array}$} & \multicolumn{2}{|c|}{ Moisture\% } & \multicolumn{2}{|c|}{$\begin{array}{c}\text { Crude } \\
\text { Protein\% }\end{array}$} & \multicolumn{2}{|c|}{ Crude Fat $\%$} & \multicolumn{2}{|c|}{ Ash\% } & \multicolumn{2}{|c|}{ Crude fiber\% } & \multicolumn{2}{|c|}{$\begin{array}{l}\text { Total Carbohy- } \\
\text { drate } \%\end{array}$} & \multicolumn{2}{|c|}{$\begin{array}{c}\text { Energy } \\
\text { (kcal/ 100g) }\end{array}$} \\
\hline \multirow{3}{*}{$\frac{\grave{3}}{\frac{0}{4}}$} & 1 & $\begin{array}{l}9 \cdot, \leqslant r \\
\pm \cdot, \cdot, 1 \\
\end{array}$ & a & $\begin{array}{r}\cdot, r q \\
\pm \cdot, \cdot,\end{array}$ & c & $\begin{array}{c}\because \cdot \cdot V \\
\pm \cdot, \cdot 1\end{array}$ & 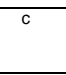 & $\begin{array}{r}\quad, \cdot 9 \\
\pm \cdot, \cdot 1 \\
\end{array}$ & $\mathrm{c}$ & $\begin{array}{c}0.080 \\
\pm 0.004 \\
\end{array}$ & $\mathrm{a}$ & $\begin{array}{c}9, \cdot r \\
\pm \cdot, \cdot r\end{array}$ & c & $\begin{array}{r}r \wedge, r \\
\pm \cdot, 12\end{array}$ & $\mathrm{c}$ \\
\hline & 2 & $\begin{array}{l}\wedge, 91 \\
\pm \cdot, \cdot, 1\end{array}$ & c & $\begin{array}{l}r, \varepsilon q \\
\pm \cdot, \cdot, 1\end{array}$ & $\mathrm{a}$ & $\begin{array}{r}-, 17 \\
., 14 \\
\pm ., .1\end{array}$ & $\mathrm{~b}$ & $\begin{array}{c}\cdot, \lambda Y \\
\pm \cdot, \cdot 1\end{array}$ & $\mathrm{a}$ & $\begin{array}{c}0.080 \\
\pm 0.004\end{array}$ & $\mathrm{a}$ & $\begin{array}{l}T \leqslant, T r \\
\pm \cdot,, r\end{array}$ & $\mathrm{a}$ & $\begin{array}{r}V r, 9 \\
\pm \cdot, 13\end{array}$ & $\mathrm{~b}$ \\
\hline & 3 & $\begin{array}{l}-1,1 \\
\pm \cdots, .1\end{array}$ & b & $\begin{array}{l}r, Y q \\
\pm \cdot, \cdot,\end{array}$ & $\mathrm{b}$ & $\begin{array}{c}, Y Y \\
\pm \cdot, \cdot 1\end{array}$ & $\mathrm{a}$ & $\begin{array}{l}\cdot, 7 \mathrm{~V} \\
\pm \cdot, \cdot 1\end{array}$ & $\mathrm{~b}$ & $\begin{array}{c}0.080 \\
\pm 0.004 \\
\end{array}$ & $\mathrm{a}$ & $\begin{array}{l}r, Y O \\
\pm \cdot, \cdot r\end{array}$ & $\mathrm{~b}$ & $\begin{array}{r}\lambda 4,0 \\
\pm,, 18\end{array}$ & $\mathrm{a}$ \\
\hline \multicolumn{2}{|c|}{ LSD / Sign ( $P \leq 0.05)$} & \multicolumn{2}{|c|}{0.021} & \multicolumn{2}{|c|}{0.023} & \multicolumn{2}{|c|}{0.003} & \multicolumn{2}{|c|}{0.002} & \multicolumn{2}{|c|}{0.005} & \multicolumn{2}{|c|}{0.041} & \multicolumn{2}{|c|}{0.115} \\
\hline \multirow{3}{*}{$\begin{array}{l}\frac{1}{5} \\
\stackrel{0}{\underline{E}} \\
\frac{ \pm}{\pi / 0} \\
\Sigma\end{array}$} & 5 & $\begin{array}{l}9 \cdot, 14 \\
\pm \cdot, \cdot 1\end{array}$ & a & $\begin{array}{l}\cdot, \varepsilon r \\
\pm \cdot, \cdot r\end{array}$ & $\mathrm{c}$ & $\begin{array}{c}\cdot, 1 \\
\pm \cdot, \cdot 1\end{array}$ & $\mathrm{c}$ & $\begin{array}{c}\cdot, \cdot \wedge \\
\pm \cdot, \cdot 1\end{array}$ & $\mathrm{c}$ & $\begin{array}{c}0.078 \\
\pm 0.003\end{array}$ & $\mathrm{a}$ & $\begin{array}{l}\text { Q,YV } \\
\pm \cdot, \cdot, \varepsilon\end{array}$ & c & $\begin{array}{r}r 9,7 \\
\pm ., 17\end{array}$ & c \\
\hline & 5 & $\begin{array}{l}-\cdot, 91 \\
\pm \cdot, \cdot, 1\end{array}$ & $\mathrm{~b}$ & $\begin{array}{l}r, \varepsilon q \\
\pm \cdot, \cdot,\end{array}$ & $\mathrm{a}$ & $\begin{array}{r}\cdot, 17 \\
\pm \cdot, \ldots\end{array}$ & $\mathrm{b}$ & $\begin{array}{l}\cdot \cdot \lambda r \\
\pm \cdot, \cdot 1\end{array}$ & $\mathrm{a}$ & $\begin{array}{c}0.078 \\
\pm 0.003 \\
\end{array}$ & $\mathrm{a}$ & $\begin{array}{l}\varepsilon, T \\
\pm \cdot, \cdot r\end{array}$ & $\mathrm{a}$ & $\begin{array}{r}\quad V r, 9 \\
\pm+, 19\end{array}$ & $\mathrm{~b}$ \\
\hline & 6 & $\begin{array}{l}-\cdot, \lambda) \\
\pm \cdot, \cdot, 1\end{array}$ & c & 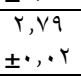 & $\mathrm{b}$ & $\begin{array}{l}r, Y O \\
\pm \cdot, \cdot 1\end{array}$ & a & $\begin{array}{r}0.66 \\
\pm 0.01 \\
\end{array}$ & $\mathrm{~b}$ & $\begin{array}{c}0.078 \\
\pm 0.003\end{array}$ & a & $\begin{array}{l}12.99 \\
\pm 0.04 \\
\end{array}$ & b & $\begin{array}{r}-1 \gamma, 9 \\
\pm \cdot, 21\end{array}$ & $\mathrm{a}$ \\
\hline \multicolumn{2}{|c|}{ LSD / Sign $(P \leq 0.05)$} & \multicolumn{2}{|c|}{0.021} & \multicolumn{2}{|c|}{0.038} & \multicolumn{2}{|c|}{0.023} & \multicolumn{2}{|c|}{0.002} & \multicolumn{2}{|c|}{0.003} & \multicolumn{2}{|c|}{0.063} & \multicolumn{2}{|c|}{0.163} \\
\hline \multicolumn{2}{|c|}{ Type of flour } & \multicolumn{2}{|c|}{ N.S } & \multicolumn{2}{|c|}{ N.S } & \multicolumn{2}{|c|}{ N.S } & \multicolumn{2}{|c|}{ N.S } & \multicolumn{2}{|c|}{ N.S } & \multicolumn{2}{|c|}{ N.S } & \multicolumn{2}{|c|}{${ }^{*}$} \\
\hline \multirow{2}{*}{\multicolumn{2}{|c|}{\begin{tabular}{|l} 
Type of liquid \\
Type of flour ${ }^{\star}$ liquid
\end{tabular}}} & ** & & & & * & & * & & $\mathbf{N}$ & & & & * & \\
\hline & & N. & & $\bar{N}$ & & $\mathbf{N}$ & & $\bar{N}$ & & $\mathbf{N}$ & & & & * & \\
\hline
\end{tabular}

\begin{tabular}{|l|c|c|}
\hline Type of flour ${ }^{\star}$ liquid & N.S & N.S \\
\hline Values in the same column with different & letters $(a, b$ \\
\hline
\end{tabular}

Values in the same column with different letters $(a, b \& c)$ are significantly different $(P \leq 0.05)$.All

$\begin{array}{ll}1=\text { control barley flour (made with water). } & 4=\text { control malt flour (made with water). } \\ 2 \text { = barley flour with Skimmed milk. } & 5=\text { malt flour with Skimmed milk. }\end{array}$

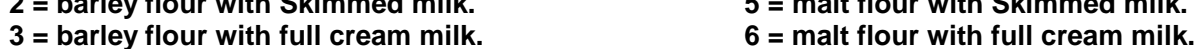

Table ( 3): Minerals contents of Talbeena ingredients ( $\mathrm{mg} / \mathrm{100 \textrm {g }}$ ) on dry weight basis:-

Component Macro Elements

\begin{tabular}{|c|c|c|c|c|c|c|c|c|c|c|c|c|c|c|c|c|}
\hline \multirow{2}{*}{$\begin{array}{l}\text { Component } \\
\text { Raw materials } \\
\end{array}$} & \multicolumn{12}{|c|}{ Macro Elements } & \multicolumn{4}{|c|}{ Micro Elements } \\
\hline & \multicolumn{2}{|l|}{$\mathrm{Na}$} & \multicolumn{2}{|l|}{ K } & \multicolumn{2}{|l|}{$\mathrm{Ca}$} & \multicolumn{2}{|l|}{$\mathbf{P}$} & \multicolumn{2}{|c|}{$\mathrm{Na} / \mathrm{K}$} & \multicolumn{2}{|c|}{$\mathrm{Ca} / \mathrm{P}$} & \multicolumn{2}{|l|}{$\mathrm{Fe}$} & \multicolumn{2}{|l|}{$\mathrm{Zn}$} \\
\hline Barley flour & $\begin{array}{l}14.64 \\
\pm 0.89\end{array}$ & a & $\begin{array}{c}388.79 \\
\pm 2.92\end{array}$ & $\mathrm{a}$ & $\begin{array}{l}82.86 \\
\pm 1.45\end{array}$ & $\mathrm{a}$ & $\begin{array}{c}324.28 \\
\pm 3.52\end{array}$ & $\mathrm{a}$ & $\begin{array}{c}0.037 \\
\pm 0.002\end{array}$ & a & $\begin{array}{c}0.256 \\
\pm 0.008\end{array}$ & a & $\begin{array}{c}2.311 \\
\pm 0.026\end{array}$ & $\mathrm{a}$ & $\begin{array}{l}4.864 \\
\pm 0.24\end{array}$ & $\mathrm{~b}$ \\
\hline Malt flour & $\begin{array}{l}12.42 \\
\pm 0.81 \\
\end{array}$ & b & $\begin{array}{r}328.11 \\
\pm 3.07 \\
\end{array}$ & b & $\begin{array}{l}66.39 \\
\pm 1.01 \\
\end{array}$ & b & $\begin{array}{c}308.12 \\
\pm 3.39 \\
\end{array}$ & $\mathrm{~b}$ & $\begin{array}{c}0.038 \\
\pm 0.005 \\
\end{array}$ & a & $\begin{array}{c}0.216 \\
\pm 0.001 \\
\end{array}$ & $\mathrm{~b}$ & $\begin{array}{c}2.323 \\
\pm 0.019 \\
\end{array}$ & a & $\begin{array}{l}5.581 \\
\pm 0.29 \\
\end{array}$ & $\mathrm{a}$ \\
\hline LSD / Sign $(P \leq 0.05)$ & $1.33^{\text {**t }}$ & & $12.91^{\text {*t }}$ & & $5.38^{* *}$ & & $9.61^{*}$ & & $0.018^{\mathrm{NS}}$ & & 0.024 & & $0.13^{\mathrm{NS}}$ & & 1.24 & \\
\hline Skimmed milk & $\begin{array}{l}396.98 \\
\pm 5.25 \\
\end{array}$ & a & $\begin{array}{l}1146.92 \\
\pm 16.53 \\
\end{array}$ & $\mathrm{a}$ & $\begin{array}{c}1243.86 \\
\pm 17.65 \\
\end{array}$ & $\mathrm{a}$ & $\begin{array}{l}977.54 \\
\pm 13.32 \\
\end{array}$ & $\mathrm{a}$ & $\begin{array}{c}0.346 \\
\pm 0.009 \\
\end{array}$ & $\mathrm{~b}$ & $\begin{array}{c}1.272 \\
\pm 0.032 \\
\end{array}$ & $\mathrm{~b}$ & $\begin{array}{c}0.668 \\
\pm 0.017 \\
\end{array}$ & $\mathrm{~b}$ & $\begin{array}{l}5.862 \\
\pm 0.08 \\
\end{array}$ & $\mathrm{a}$ \\
\hline Full cream milk & $\begin{array}{l}260.71 \\
\pm 4.05\end{array}$ & b & $\begin{array}{l}-171.43 \\
\pm 11.21\end{array}$ & $\mathrm{~b}$ & $\begin{array}{c}919.53 \\
\pm 6.59\end{array}$ & $\mathrm{~b}$ & $\begin{array}{l}548.18 \\
\pm 12.56 \\
\end{array}$ & $\mathrm{~b}$ & $\begin{array}{c}0.268 \\
\pm 0.013\end{array}$ & $\mathrm{a}$ & $\begin{array}{c}1.678 \\
\pm 0.054\end{array}$ & $\mathrm{a}$ & $\begin{array}{c}2.520 \\
\pm 0.054\end{array}$ & $\mathrm{a}$ & $\begin{array}{l}2.279 \\
\pm 0.28\end{array}$ & $\mathrm{~b}$ \\
\hline LSD / Sign $(P \leq 0.05)$ & 44.36 & & $21.89^{* *}$ & & $57.43^{*+4}$ & & $44.54^{*}$ & & $0.049^{*}$ & & $0.166^{*}$ & & $0.22^{* *}$ & & $1.17^{*}$ & \\
\hline
\end{tabular}

Values in the same column with different letters (a \& b) are significantly different $(P \leq 0.05)$.

All values are means of three replicates \pm SD. 